\title{
Cerebral autosomal dominant arteriopathy with subcortical infarcts and leukoencephalopathy (CADASIL) in Argentina
}

\author{
Arteropatia cerebral autosomal dominante com infartos subcorticais e \\ leucoencefalopatia (CADASIL) na Argentina

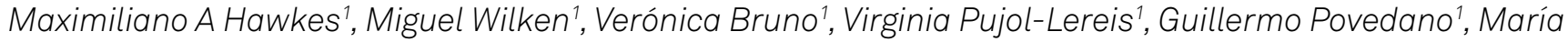 \\ Saccoliti², Analia Taratuto², Sebastián F Ameriso'
}

\begin{abstract}
CADASIL is the most common cause of hereditary stroke and vascular dementia. Published information about this disease in South America is scant. We describe clinical and demographic characteristics of 13 patients (10 families) with CADASIL from Argentina. Methods: Medical records, diagnostic tests and family history of patients with CADASIL were reviewed. Results: Thirteen patients with CADASIL (10 families) were included. All patients had European ancestry. Initial presentation was stroke in most patients $(n=11)$. Stroke patients later developed cognitive complaints $(n=9)$, migraine with aura $(n=1)$, apathy $(n=4)$ and depression $(n=6)$. External capsule and temporal lobe involvement on MRI were characteristic imaging findings. Two patients died after intracerebral hemorrhage. Conclusion: This is the first report of non-related patients with CADASIL in South America addressing ancestry. Since European ancestry is not highly prevalent in all South American countries, there may be variable incidence of CADASIL within this region.
\end{abstract}

Keywords: CADASIL, stroke, South America, leukoencephalopathy, vascular dementia.

\section{RESUMO}

CADASIL é a causa mais frequente de acidente vascular cerebral e demência hereditários. São poucas as publicações sobre esta doença na América do Sul. Aqui descrevemos dados clínicos e demográficos de 13 pacientes (10 famílias) da Argentina com CADASIL. Métodos: Prontuários médicos testes diagnósticos e história familiar de pacientes com CADASIL foram revisados. Resultados: Treze pacientes com CADASIL (10 famílias) foram incluídos. Todos os pacientes tinha ancestralidade europeia. A apresentação inicial foi acidente vascular cerebral na maioria dos pacientes $(n=11)$. Pacientes com acidente vascular cerebral depois desenvolveram alterações cognitivas $(n=9)$, enxaqueca com aura $(n=1)$, apatia $(n=4)$ e depressão $(n=6)$. Os achados de imagem característicos da RM foram na cápsula externa e no lobo temporal. Dois pacientes morreram por hemorragia intracerebral. Conclusão: Este é o primeiro relato de série de casos de pessoas não relacionadas entre si que apresentavam CADASIL na América do Sul, discutindo ancestralidade. Uma vez que a ascendência europeia tem prevalência variada em diferentes países da América do Sul, é possível que esta seja uma variável de incidência de CADASIL nesta região.

Palavras-chave: CADASIL, acidente vascular cerebral, América do Sul, leucoencefalopatia, demência vascular.

Cerebral Autosomal Dominant Arteriopathy with Subcortical Infarcts and Leucoencephalopathy (CADASIL) is the most common cause of hereditary stroke and vascular dementia ${ }^{1}$. It is caused by mutations in the NOTCH3 gene located in chromosome $19^{2}$. Subcortical ischemic strokes (60-85\%), cognitive impairment (40-50\%), migraine with aura (20-40\%), depression (20\%), and apathy (40\%) are the most prevalent symptoms ${ }^{1}$. An increased risk of intracerebral hemorrhage (ICH) has also been reported in these patients ${ }^{3,4,5,6}$.
Clinical suspicion is based on typical symptoms, family history, and specific findings in magnetic resonance imaging $(\mathrm{MRI})^{1}$. While family history is almost always present, de novo mutations have also been described ${ }^{7,8}$.

Genetic test assessing for NOTCH3 mutations or skin biopsy investigating the presence of granular osmiophilic material (GOM) are required for definitive diagnosis ${ }^{1}$. Management strategies consist of vascular risk factor (VRF) control, antiaggregation, and, when appropriate, genetic counseling.

\footnotetext{
${ }^{1}$ Neurological Research Institute Raúl Carrea, FLENI, Departament of Neurology, Buenos Aires, Argentina; ${ }^{2}$ Neurological Research Institute Raúl Carrea, FLENI, Departament of Pathology, Buenos Aires, Argentina. Correspondence: Maximiliano A Hawkes; Montañeses 2325; Postal Code: 1428 Ciudad de Buenos Aires, Argentina; E-mail:mhawkes@fleni.org.ar Conflict of interest: There is no conflict of interest to declare.

Received 10 March 2015; Received in final form 24 April 2015; Accepted 14 May 2015.
} 
To the best of our knowledge this is the first case series report of CADASIL in South America.

We describe clinical and demographic characteristics of 13 patients from 10 families with diagnosis of CADASIL from a single center in Argentina.

\section{METHOD}

Retrospective review of medical records and diagnostic tests of patients with CADASIL. Genetic test was not widely available in Argentina at the time of this report. Thus, most patients were diagnosed by skin biopsy samples. A single specialized laboratory studied all samples. Family history was documented in all cases. Patients or patient's relatives were contacted to complete missing information and to update vital status. All subjects provided consent. The ethics committee of the institution approved the study.

\section{RESULTS}

We report 13 patients $(7$ men) with diagnosis of CADASIL from 10 families, aged $48 \pm 9$ (40-73) years old at time of diagnosis (Table). Follow up was between 3 months and 10 years. Diagnosis was established by skin biopsy in 11 patients, and by genetic testing performed abroad in two cases. Ultrastructural study of the skin biopsies showed GOM deposits, mainly in the thickened basement membrane of arteries or capillaries (Figure 1).

All patients had European ancestry: Spanish $(\mathrm{n}=8)$, Greek ( $n=1)$, Russian/Polish $(n=2)$, Portuguese $(n=1)$, Ukrainian $(n=1)$. Three patients had no familiar history of symptoms suggestive of CADASIL. Initial clinical presentations were: ischemic stroke $(n=11)$, migraine with aura $(n=1)$, and cognitive complaint $(n=1)$. All stroke patients later developed other symptoms: cognitive complaint $(n=9)$, migraine with aura $(n=1)$, apathy $(n=4)$, and depression $(n=6)$.

Cognitive impairment was diagnosed by neurological examination in six patients and by neuropsychological testing in four. Five patients were men and five women.

All patients had brain MRI. Typical lesions were found in external capsule $(n=11)$ and temporal lobes $(n=10)$. Only two had microbleeds (Figure 2). Two patients reveled asymptomatic acute infarcts in routine follow-up MRIs. Associated vascular risk factor were hypertension $(n=7)$, dyslipemia $(n=9)$, smoking $(n=4)$, type 2 diabetes mellitus $(n=2)$ and patent foramen ovale $(\mathrm{PFO})(\mathrm{n}=2)$. All patients received risk factor control and antiplatelet treatment. Two of them were empirically anticoagulated. Two patients died during follow up as result of intracranial hemorrhage $(\mathrm{ICH})$, one was on aspirin and the other was on warfarin. Currently eleven patients are on aspirin or clopidogrel. Modified Rankin scale was $<3$ in 9 surviving subjects and $\geq 3$ in 2 .

Six asymptomatic family members were evaluated (physical examination and brain MRI). One had chronic headache. A 38 year-old woman presented white matter lesions not-typical of CADASIL. Three relatives in two families underwent skin biopsy after MRI. It was normal in all cases.

\section{DISCUSSION}

CADASIL clinical and imaging patterns in this Argentinean population of European ancestry appear similar to those described in Northern hemisphere populations.

\begin{tabular}{lc} 
Table. Population characteristics. & $\mathrm{N}=13$ \\
\hline Total & 7 \\
\hline Gender & 6 \\
Male & 13 \\
Female & $48 \pm 9$ \\
European ancestry & \\
Median age at symptoms onset (years \pm SD) & 11 \\
Initial presentation & 1 \\
Stroke & 1 \\
Cognitive impairment & \\
Migraine with aura & 10 \\
Symptoms in the follow up & 6 \\
Cognitive impairment & 4 \\
Depression & 1 \\
Apathy & \\
Migraine with aura & 11 \\
Diagnostic tests & 10 \\
MRI - External capsule involvement & 2 \\
$\quad$ - Temporal pole involvement & 11 \\
- Microbleeds & 2 \\
Skin biopsy & \\
Genetic test &
\end{tabular}

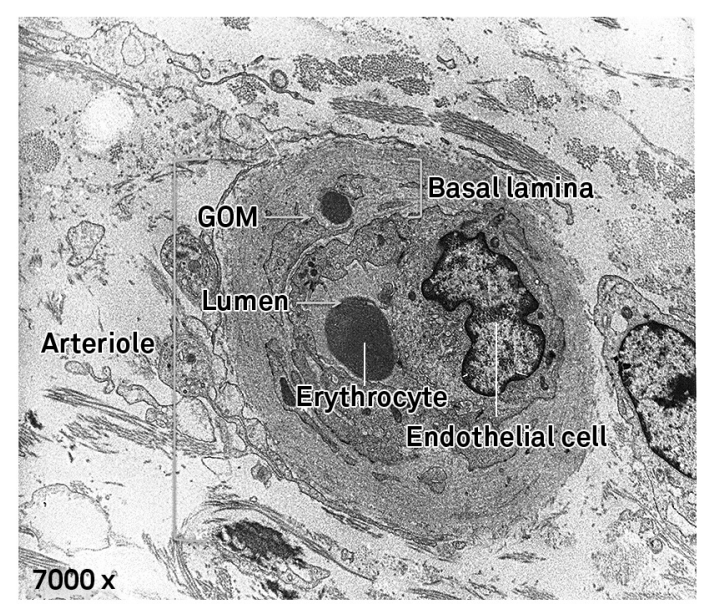

Figure 1. Skin biopsy sample (transmission electron microscope). 

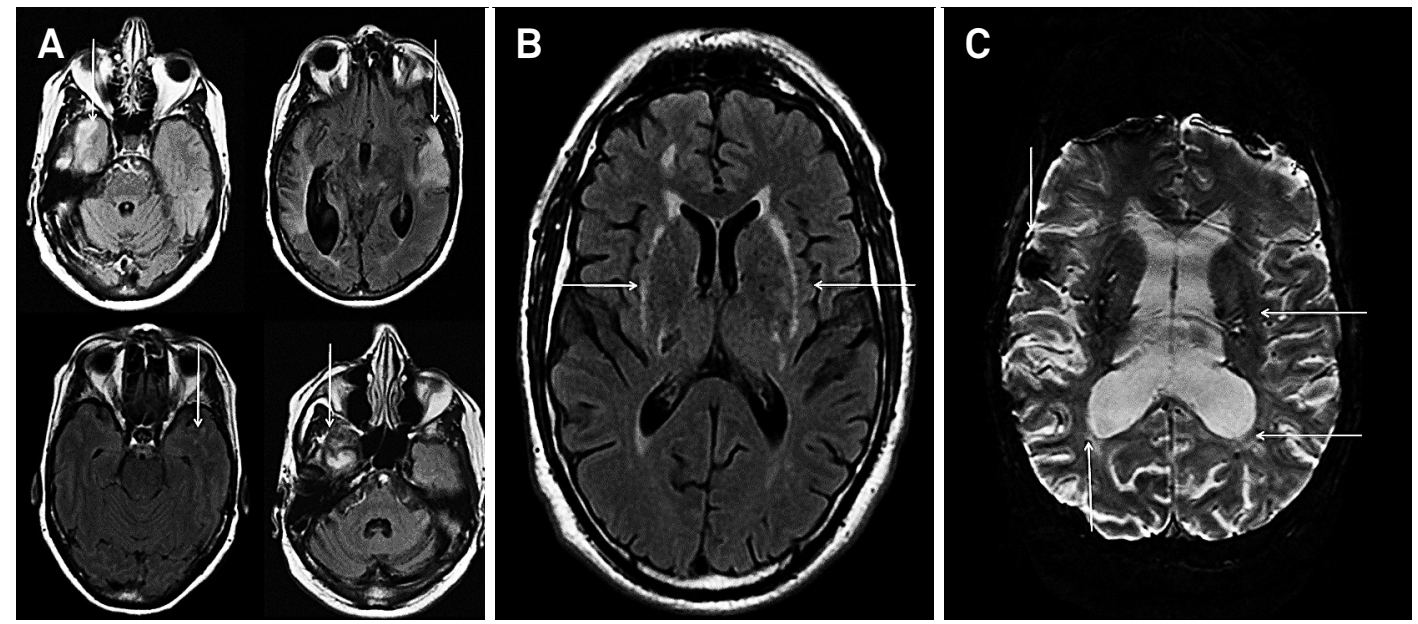

Figure 2. MRI findings. Temporal pole (A) and external capsule involvement (B). Microbleeds (C).

Three patients had no familiar history of CADASIL. False-negative family history is commonly documented in individuals presenting with features of CADASIL and is associated with initial misdiagnosis ${ }^{9}$.

Stroke was the leading presenting symptom ${ }^{1}$. As no treatment to modify disease progression is available, our patients are under risk factor control and single antiplatelet treatment.

Cognitive impairment affects up to $50 \%$ of patients ${ }^{1}$. We found it in ten patients and it was the initial symptom in two. The latter findings are consistent with those reported in a single large family in Colombia ${ }^{10}$. Depression and apathy are described in $20-50 \%$ and $40 \%$ of CADASIL patients respectively ${ }^{1}$. Incidences in our population were similar to those described in the literature.

The proportion of migraine with aura in CADASIL patients is five times higher than in general population ${ }^{1}$. Five of our patients had migraine, two with and three without aura. Our series supports findings reporting that migraine without aura frequency is slightly higher in CADASIL patients compared with the general population ${ }^{11}$.

Increased risk of ICH in CADASIL patients is based on case reports and it has not been proved with controlled studies. Approximately 22 cases of ICH in CADASIL patients have been reported ${ }^{3,4}$. In our series, one hypertensive male treated with warfarin and one non-hypertensive woman treated with aspirin died after ICH.

Genetic test screening for the 23 exons of the EGFR is the gold standard for the diagnosis of CADASIL (sensitivity and specificity of almost $100 \%)^{1}$. Skin biopsy has been restricted to patients with negative genetic test with highly suggestive features of CADASIL or identification of a new sequence of unknown significance, with a $100 \%$ of specificity and $96 \%$ or more sensitivity ${ }^{12,13}$. Operator skills, number of arteries examined, and adhesion to guidelines for GOM identification could influence the sensitivity of the technique ${ }^{14}$. Skin biopsy examined by experienced observers was a suitable option in our population as complete genetic test of all 23 exons is not available in Argentina.

GOM deposits are located both in small and medium sized arteries and capillaries, in contact with vascular smooth muscle cells (VSMC) or within the thickened basement membrane. Vein walls may also be involved.

Cerebral MRI adds valuable information to clinical suspicion. Changes in external capsule and temporal pole were found in eleven and ten patients respectively. While the first one is an earlier less specific finding, temporal pole involvement has been described as a radiologic marker of CADASIL ${ }^{15}$. Microbleeds are detected in $31-69 \%$ of CADASIL patients 4 . We found them in two subjects (15\%). The number of young patients ( $83 \%$ were under 55 year-old), an adequate hypertension control could explain the low incidence in our population. Two patients showed asymptomatic acute cerebral infarcts in DWI/MRI during follow-up. This finding has been reported in $10 \%$ of CADASIL patients compared with $8 \%$ of patients with small-vessel disease ${ }^{16}$.

Prevalence of PFO in CADASIL is up to $47 \%{ }^{17}$. We found it in two patients. This finding may be related to NOTCH receptor family participation in the cardiovascular system development ${ }^{18}$.

Brain MRI was performed in six asymptomatic relatives of 3 different families. Only a 38 year-old female showed white matter lesions. Three of them underwent skin biopsy. It was normal in all cases. These findings are consistent with a recent report in which only $33 \%$ of patients that had undergone a multistep genetic counseling finally took the genetic test. Reasons for drop out were not reported ${ }^{19}$.

In conclusion, we report the first case series of patients with CADASIL in South America. Published data in our region is scant. This can be due to low suspicion threshold and limited access to diagnostic tools. As European ancestry is not highly prevalent in all South American countries there 
may be a variable incidence of CADASIL within this region. The Amerindian and African contributions to the gene admixture in the population of Buenos Aires are $15 \%$ and $4 \%$ respectively ${ }^{20}$. Hence European ancestry in this population is an important factor to take into account.

If MRI is not available the number of misdiagnosis may be high. In countries where genetic test screening for all the
23 exons of EFGR is not available, skin biopsy assessed by trained pathologists is a suitable option.

Studies to clarify the risk of ICH with antiaggregation and anticoagulation treatment in CADASIL patients are needed. Since CADASIL is heterogeneous regarding clinical manifestations and severity grade depending on genotype, studies examining the genetic profile in our population are warranted.

\section{References}

1. Chabriat H, Joutel A, Dichgans M, Tournier-Lasserve E, Bousser MG: Cadasil. Lancet Neurol 2009;8:643-653.

2. Joutel A, Corpechot C, Ducros A, Vahedi K, Chabriat H, Mouton P et al. Notch3 mutations in cadasil, a hereditary adult-onset condition causing stroke and dementia. Nature. 1996;383(6602):707-10. doi:10.1038/383707a0

3. Lian L, Li D, Xue Z, Liang Q, Xu F, Kang H et al. Spontaneous intracerebral hemorrhage in CADASIL.J Headache Pain. 2013;14(1):98. doi:10.1186/1129-2377-14-98

4. Rinnoci V, Nannucci S, Valenti R, Donnini I, Bianchi S, Pescini F et al. Cerebral hemorrhages in CADASIL: report of four cases and a brief review. J Neurol Sci. 2013;330(1-2):45-51. doi:10.1016/j.jns.2013.04.002

5. Dichgans M, Holtmannspötter M, Herzog J, Peters N, Bergmann $M$, Yousry TA. Cerebral microbleeds in CADASIL: a gradient-echo magnetic resonance imaging and autopsy study. Stroke. 2002;33(1):67-71. doi:10.1161/hs0102.100885

6. Lesnik Oberstein SA, Boom R, Buchem MA, Houwelingen HC, Bakker E, Vollebregt E et al. Cerebral microbleeds in cadasil. Neurology. 2001;57(6):1066-70. doi:10.1212/WNL.57.6.1066

7. Joutel A, Dodick DD, Parisi JE, Cecillon M, Tournier-Lasserve E, Bousser MG. De novo mutation in the Notch3 gene causing CADASIL. Ann Neurol. 2000;47(3):388-91. doi:10.1002/15318249(200003)47:3<388::AID-ANA19>3.0.CO;2-Q

8. Coto E, MenÉndez M, Navarro R, Garcĺa-Castro M, Alvarez V. A new de novo Notch3 mutation causing CADASIL. Eur J Neurol. 2006;13(6):628-31. doi:10.1111/j.1468-1331.2006.01337.x

9. Razvi SS, Davidson R, Bone I, Muir KW. Is inadequate family history a barrier to diagnosis in CADASIL? Acta Neurol Scand.2005;112(5):323-26. doi:10.1111/j.1600-0404.2005.00495.x

10. Lopera F, Arboleda J, Moreno S, Almeida N, Cuartas M, Arcos-Burgos M. [Clinical characteristics of hereditary cerebrovascular disease in a large family from Colombia]. Rev Neurol. 2000;31(10):901-7.
11. Liem MK, Oberstein SA, van der Grond J, Ferrari MD, Haan J. CADASIL and migraine: a narrative review. Cephalalgia. 2010;30(11):1284-9. doi:10.1177/0333102410370870

12. Kalaria RN, Viitanen M, Kalimo H, Dichgans M, Tabira T. The pathogenesis of CADASIL: an update.J Neurol Sci. 2004;226(1-2):35-9. doi:10.1016/j.jns.2004.09.008

13. Tikka S, Mykkänen K, Ruchoux MM, Bergholm R, Junna M, Pöyhönen $\mathrm{M}$ et al. Congruence between NOTCH3 mutations and GOM in 131 CADASIL patients. Brain. 2009;132(4):933-9. doi:10.1093/brain/awn364

14. Morroni M, Marzioni D, Ragno M, Di Bella P, Cartechini E, Pianese $L$ et al. Role of electron microscopy in the diagnosis of cadasil syndrome: A study of 32 patients. PLoS One. 2013;8(6):e65482. doi:10.1371/journal.pone.0065482

15. O'Sullivan M, Jarosz JM, Martin RJ, Deasy N, Powell JF, Markus HS. MRI hyperintensities of the temporal lobe and external capsule in patients with cadasil. Neurology. 2001;56(5):628-34. doi:10.1212/WNL.56.5.628

16. O'Sullivan M, Rich PM, Barrick TR, Clark CA, Markus HS. Frequency of subclinical lacunar infarcts in ischemic leukoaraiosis and cerebral autosomal dominant arteriopathy with subcortical infarcts and leukoencephalopathy. AJNR Am J Neuroradiol. 2003;24(7):1348-54.

17. Zicari E, Tassi R, Stromillo ML, Pellegrini M, Bianchi S, Cevenini G et al. Right-to-left shunt in CADASIL patients: prevalence and correlation with clinical and MRI findings. Stroke. 2008;39(7):2155-7. doi:10.1161/STROKEAHA.107.506311

18. Niessen K, Karsan A. Notch signaling in the developing cardiovascular system. Am J Physiol Cell Physiol. 2007;293(1):C1-11. doi:10.1152/ajpcell.00415.2006

19. Reyes S, Kurtz A, Hervé D, Tournier-Lasserve E, Chabriat H. Presymptomatic genetic testing in CADASIL.J Neurol. 2012;259(10):2131-6. doi:10.1007/s00415-012-6468-8

20. Avena SA, Goicochea AS, Rey J, Dugoujon JM, Dejean CB, Carnese FR. [Gene mixture in a population sample from Buenos Aires City]. Medicina (B. Aires). 2006;66(2):113-8. Spanish. 